\title{
MORPHOLOGICAL DIFFERENTIATION AND DISTRIBUTION OF NON-GLANDULAR AND GLANDULAR TRICHOMES ON Dracocephalum moldavicum L. SHOOTS
}

\author{
Marta Dmitruk, Elżbieta Weryszko-Chmielewska
}

\author{
Department of Botany, University of Life Science, \\ Akademicka 15, 20-950 Lublin, Poland \\ e-mail: elzbieta.weryszko@up.lublin.pl
}

Received: 15.04 .2010

\begin{abstract}
The structure, micromorphology and distribution of trichomes on Dracocephalum moldavicum L. shots were investigated using light and scanning electron microscopy (SEM). There were distinguished 3 types of non-glandular trichomes, 3 types of glandular trichomes and papillae of the osmophore in the epidermis of the corolla. The highest density of non-glandular and glandular trichomes was found on the abaxial surface of the calyx, on bracts and in the upper part of the stem. Structural variations in the head and stalk of long glandular trichomes were demonstrated. The dimensions of particular types of trichomes are given in the present paper.

Differences in the structure of the trichomes of this species are presented, compared to literature data. The micromorphology of particular trichome types is documented in numerous photographs showing the rich ornamentation of the cuticle of non-glandular trichomes.
\end{abstract}

Key words: Dracocephalum moldavicum L., non-glandular and glandular trichomes, micromorphology, flower, bract, leaf, stem

\section{INTRODUCTION}

Moldavian dragonhead (Dracocephalum moldavicum L.) is native to the Himalayas and southern Siberia. It was brought to Europe in the 16th century and grown in gardens. This is an annual plant, reaching $60 \mathrm{~cm}$ in height and with sapphire-coloured flowers, which has ornamental values. Due to its production of essential oils, this plant finds application in the food and cosmetics industries as well as in therapeutics (Kubiak, 1959; Rutk ow ski, 1998; S zwe y k o w s c y, 2003). The high attractiveness of this plant to bees is attributable to its scent and the secretion of large amounts of nectar by its flowers (Maurizio and G raf 1, 1969; Li pi ń s k i , 1976).
In Lamiaceae, odorous compounds are emitted by glandular trichomes of different structure. Over the recent years, research has been conducted on the micromorphology, ultrastructure and phytochemical characters of the trichomes found in different plant species of this family (B in i Maleci et al. 1992; S chulze et al. 1992; Ozkan and Soy, 2007; Gi ulia$\mathrm{ni}$ and Maleci Bini, 2008). The results of these studies find application in pharmacognosy and plant taxonomy. This research is also designed to explain the biosynthesis of essential oils and their importance in plant life. For many years, the trichome types have been used to classify plant genera and species in some families as well as to assess interspecific hybrids (E s a u , 1963).

Research on the trichomes of Dracocephalum moldavicum L. was carried out in earlier studies by many authors (Kubiak, 1959; Lyapunowa et al. 1975; Shavarda et al. 1990; Telepova et al. 1992). Nevertheless, existing data differ from one another and do not fully document the details of the structure of the trichomes in this species. Therefore, a study was undertaken on the structure, micromorphology and distribution of trichomes on different parts of the shoot of Dracocephalum moldavicum, using light and scanning electron microscopy.

\section{MATERIALS AND METHODS}

Dracocephalum moldavicum L. plants were obtained from a collection of medicinal plants of the Medical University of Lublin.

The distribution and types of trichomes on stems, leaves, bracts, calyx and corolla were investigated. 
Light and scanning electron microscopy (SEM) was used. Observations and measurements of trichomes obtained from fresh plant material were made with the aid of a light microscope. In order to determine the polyphenol content in trichome cells, $\mathrm{FeCl}_{3}$ was used as the histochemical test, while the presence of flavonoids was detected after the slides were treated with $\mathrm{AlCl}_{3}$.

The distribution of trichomes on particular parts of the shoot was examined in a scanning electron microscope. Their micromorphology was also determined. Fragments of different shoot parts were fixed in $4 \%$ glutaraldehyde and $0.1 \mathrm{M}$ phosphate buffer with a $\mathrm{pH}$ of 7.0 at room temperature for 4 hours. After dehydration in ethanol and acetone series, the plant samples were critical-point dried in liquid $\mathrm{CO}_{2}$ and subsequently coated with gold. Observations were performed with the aid of a Tesla BS-340 scanning electron microscope.

To identify the types of the investigated trichomes, we used the terminology presented in many publications over the recent years (e.g. Giuliani and Maleci Bini, 2008) and earlier by Payne (1978).

\section{RESULTS}

Different types of non-glandular and glandular trichomes (Figs 1,2; Table 1) were found on all the examined organs of Moldavian dragonhead, i.e. petals, sepals, bracts, leaves, and stems (Fig. 1A). In addition, on the surface of the lower corolla lip there were observed papillose epidermal cells which were covered with a striated cuticle (Fig. 1 B-D). This layer has a structure similar to that of the osmophore, a gland secreting odorous substances in flowers. Under the influence of the accumulated secretion, the cuticle layer became bulged and the striae stretched (Fig. 1C) on the surface of the cells of this tissue, and circular or oval smooth marks were left at the apex of the papillae after the emission of the secretion (Fig. 1 B,D).

\section{Types of non-glandular trichomes}

$$
\begin{aligned}
& \text { A - Unicellular (arrect) } \\
& \text { B - Multicellular (arrect, arthrodactylous) } \\
& \text { C - Long narrow (acerate) }
\end{aligned}
$$

Type A - Unicellular arrect trichomes. They reach an average length of $36 \mu \mathrm{m}$ (Table 2). These trichomes are sharp-pointed, erect or bent (Figs 3H, $4 \mathrm{~A}, \mathrm{~B}$ ), or rounded at the tip (Fig. $4 \mathrm{H})$. The wall surface is often covered with cuticular micropapillae. These are living trichomes. They have a vacuolized protoplast and numerous plastids in which the presence of flavonoids was shown histochemically.
Type B - Multicellular trichomes. They have an average length of $97 \mu \mathrm{m}$ (Table 2). They are uniseriate, unbranched, composed of 2-4 cells. Erect trichomes or trichomes bent at different levels are found within this type. Cuticular papillae are observed most frequently on the surface wall (Figs $3 \mathrm{~A}-\mathrm{G}, \mathrm{I}, \mathrm{J}$; 4 C-G). Similarly to unicellular trichomes, they are composed of living cells containing numerous plastids.

Type C - Long narrow trichomes. They are composed of 1-6 cells with an average length reaching $328 \mu \mathrm{m}$. They are narrowed at the apical part and bent in different directions. These trichomes are found only on the petals of the corolla (Figs 1 E,F; 4 I,J). They are composed of living cells containing chloroplasts and show a high degree of vacuolization.

\section{Types of glandular trichomes}

D - Peltate (cup-shaped)

E - Short capitate (brevicollate)

F - Long capitate (asciiform)

Type D - Peltate trichomes. Together with the secretion, they are ca. $61 \mu \mathrm{m}$ in length and $76 \mu \mathrm{m}$ in diameter (Table 2). They are made up of one basal cell, a short unicellular stalk and 8-12 secretory cells covered with a cuticle, beneath which a large subcuticular space is formed (Figs 5A-C; 6 A-J). The secretory cells contain chloroplasts.

Type E - Short capitate trichomes. They reach an average length of $20 \mu \mathrm{m}$ (Table 2). They are made up of one basal cell, one or two cells forming the stalk and two secretory cells within the head which is covered with a cuticle layer (Figs 5 D-G; 7 A-E).

Type F - Long capitate trichomes. They have an average length of $56 \mu \mathrm{m}$ (Table 2). They develop a multicellular (2-3 cells) uniseriate stalk and a unicellular glandular head covered with a cuticle (Figs 5 H-J, 7 F-M). Within this trichome type, there were observed different shapes of the cells composing the head: spherical or significantly elongated, some of them narrowed in the lower or middle part. A characteristic feature of these trichomes was the occurrence of a strongly vacuolized cytoplasm only in the lower, most elongated cell of the stalk. But the cells lying nearest the head had a dense cytoplasm, typical of secretory cells. The presence of flavonoids was found in the plastids of the cells of these hairs after the application of the histochemical test. 


\section{Distribution of trichomes}

The highest density of non-glandular trichomes was observed in the throat of the corolla (Fig. 1E), in the abaxial epidermis of the calyx (Fig. 2A), and on the stem (Figs 2E,F). It was also found that the glandular trichomes were distributed unevenly on the particular organs (Fig. 2, Table 1).

Glandular trichomes of different type were found in highest density on the calyx and bracts (Table 1). The adaxial and abaxial parts of the corolla were covered with peltate (D) and short capitate trichomes (E). Both surfaces of this organ were devoid of type $F$ trichomes. All the types of glandular trichomes were found on the abaxial surface of the calyx, whereas the trichomes of type D and F were not observed on the adaxial part turned towards the corolla. The bracts had a higher density of glandular trichomes on the abaxial surface than on the adaxial one. More glandular trichomes were also found on the abaxial surface of the leaves located on the stem outside the inflorescence.

The largest amount of long capitate trichomes (type F) was found on the stem. Type D and F trichomes were encountered much less frequently (Table 1).

Table1.

Distribution of different types of trichomes on particular parts of the shoot of Dracocephalum moldavicum L.

\begin{tabular}{|c|c|c|c|c|c|c|c|c|c|}
\hline \multirow{2}{*}{ Types of trichomes } & \multicolumn{2}{|c|}{ Corolla } & \multicolumn{2}{|c|}{ Calyx } & \multicolumn{2}{|c|}{ Bract } & \multicolumn{2}{|c|}{ Leaf } & \multirow{2}{*}{ Stem } \\
\hline & Adax & Abax & Adax & Abax & Adax & Abax & Adax & Abax & \\
\hline \multicolumn{10}{|l|}{ Non-glandular trichomes } \\
\hline A - Unicellular (arrect) & - & - & + & ++ & ++ & ++ & ++ & ++ & + \\
\hline $\begin{array}{c}\text { B - Multicellular (arrect, } \\
\text { arthrodactylous) }\end{array}$ & - & - & + & +++ & + & +++ & + & ++ & +++ \\
\hline C - Long narrow (acerate) & + & + & - & - & - & - & - & - & - \\
\hline \multicolumn{10}{|l|}{ Glandular trichomes } \\
\hline D - Peltate & ++ & + & - & +++ & + & ++ & + & + & + \\
\hline E-Capitate short & + & + & + & +++ & + & +++ & + & ++ & + \\
\hline F - Capitate long & - & - & - & + & + & + & + & + & +++ \\
\hline $\begin{array}{l}\text { - absent } \\
+ \text { few hairs } \\
++ \text { medium coverage } \\
+++ \text { dense coverage }\end{array}$ & & & & & & & & & \\
\hline
\end{tabular}

Table 2.

Dimensions of trichomes found on Dracocephalum moldavicum L. shoots

\begin{tabular}{|c|c|c|c|c|c|c|}
\hline \multirow{2}{*}{ Types of trichomes } & \multicolumn{3}{|c|}{ Height $(\mu \mathrm{m})$} & \multicolumn{3}{|c|}{ Diameter $*(\mu \mathrm{m})$} \\
\hline & Min. & Max. & Mean & Min. & Max. & Mean \\
\hline \multicolumn{7}{|l|}{ Non-glandular trichomes } \\
\hline \multirow{3}{*}{$\begin{array}{l}\text { A - Unicellular (arrect) } \\
\text { B - Multicellular (arrect, } \\
\text { arthrodactylous) } \\
\text { C - Long narrow (acerate) }\end{array}$} & 18.2 & 65.0 & 36.2 & 13.0 & 31.0 & 21.8 \\
\hline & 50.8 & 167.0 & 97.2 & 12.7 & 38.0 & 18.0 \\
\hline & 249.6 & 390.0 & 328.1 & 15.6 & 28.6 & 22.9 \\
\hline \multicolumn{7}{|l|}{ Glandular trichomes } \\
\hline \multirow{3}{*}{$\begin{array}{l}\text { D - Peltate } \\
\text { E - Capitate short } \\
\text { F - Capitate long }\end{array}$} & 43.7 & 70.6 & 61.4 & 64.5 & 81.9 & 75.9 \\
\hline & 16.8 & 23.2 & 20.5 & 18.3 & 21.1 & 18.7 \\
\hline & 50.5 & 62.4 & 56.5 & 17.8 & 20.1 & 19.4 \\
\hline
\end{tabular}

- The diameter was measured at the widest place of the trichome 

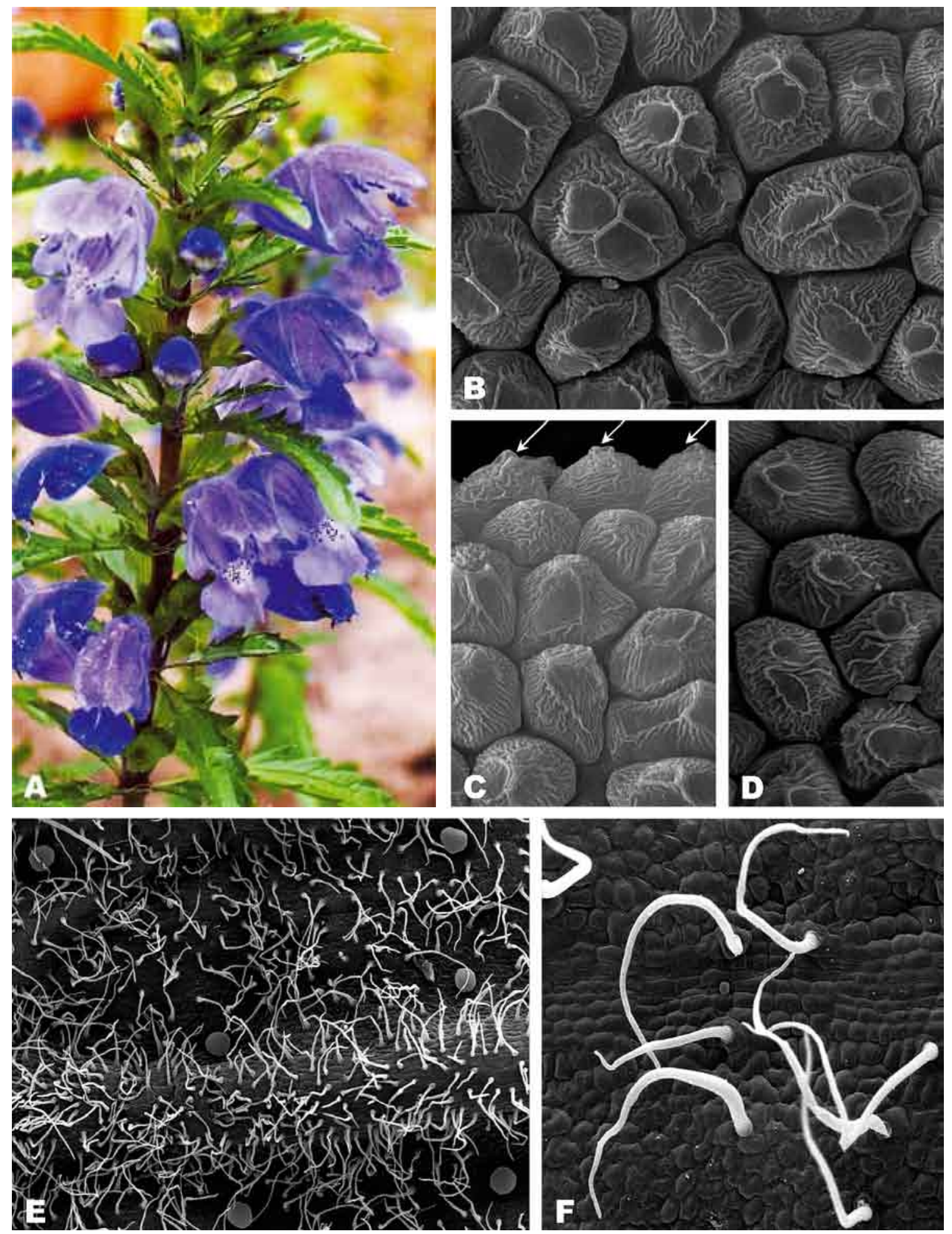

Fig. 1. Inflorescence of Dracocephalum moldavicum as well as different types of trichomes and osmophores found in the epidermis of the corolla

A - Numerous two-lipped flowers in the inflorescence with colour pattern on the lower lip.

B - D -Surface of papillose epidermal cells of the corolla, composing the osmophore; visible are cuticle striations and spherical or oval marks after secretion vesicles as well as cuticle projections (arrows) at places of secretion accumulation B-x 2400, C-x 1500, D -x1700.

E - Long non-glandular trichomes and peltate trichomes on the surface of the lower corolla lip, x 60 .

F - Long non-glandular trichomes bent in different directions. 

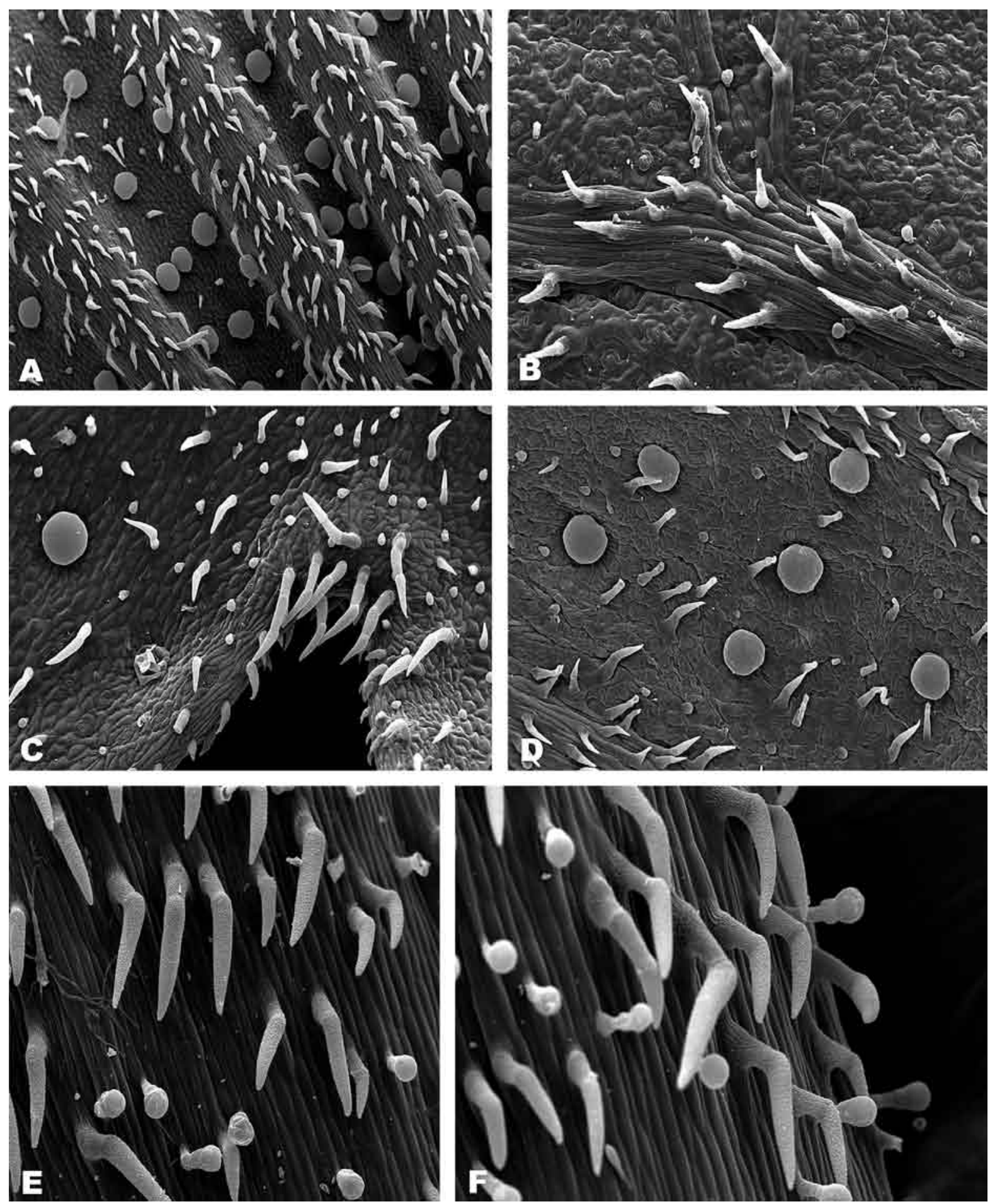

Fig. 2. Distribution of trichomes on different organs of Dracocephalum moldavicum

A - Abaxial surface of the corolla, $x 75$,

B - Abaxial surface of the lamina, $x$ 125,

C - Fragment of the apical part of the calyx, $x 110$,

D - Abaxial surface of the bract, $x 100$,

E, F- Non-glandular and glandular trichomes in the upper part of the stem,

E x 250,

$\mathrm{F}-\mathrm{x} 300$. 

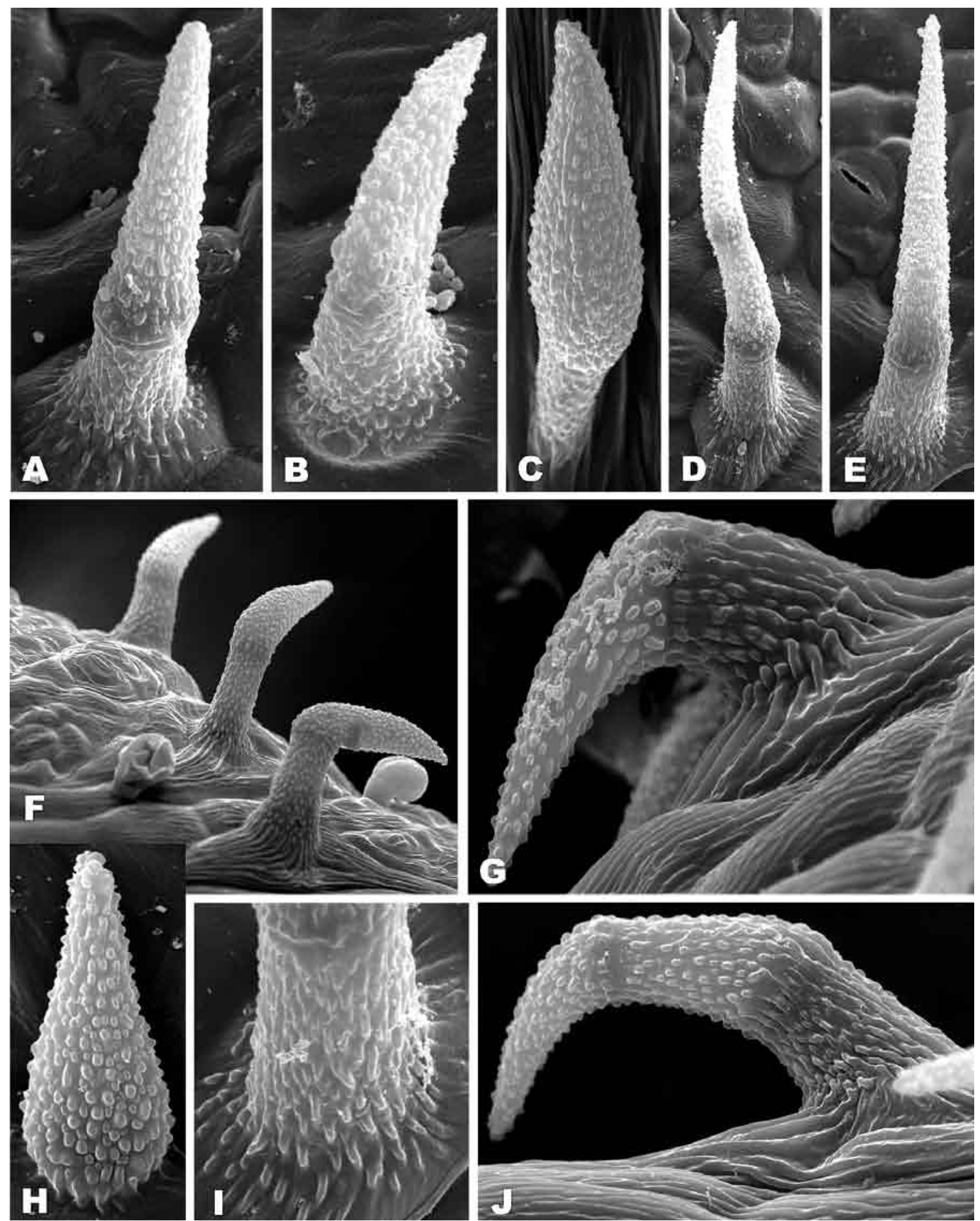

Fig. 3 A-J. Different types of erect and bent non-glandular trichomes of Dracocephalum moldavicum with visible papillae and cuticle striation on the wall surface, A - x980, B- x1450, C - x1250, D - x550, E - x770, F-x600, G - x1800, H - x1500, $\mathrm{I}-\mathrm{x} 2000, \mathrm{~J}-\mathrm{x} 1300$. 

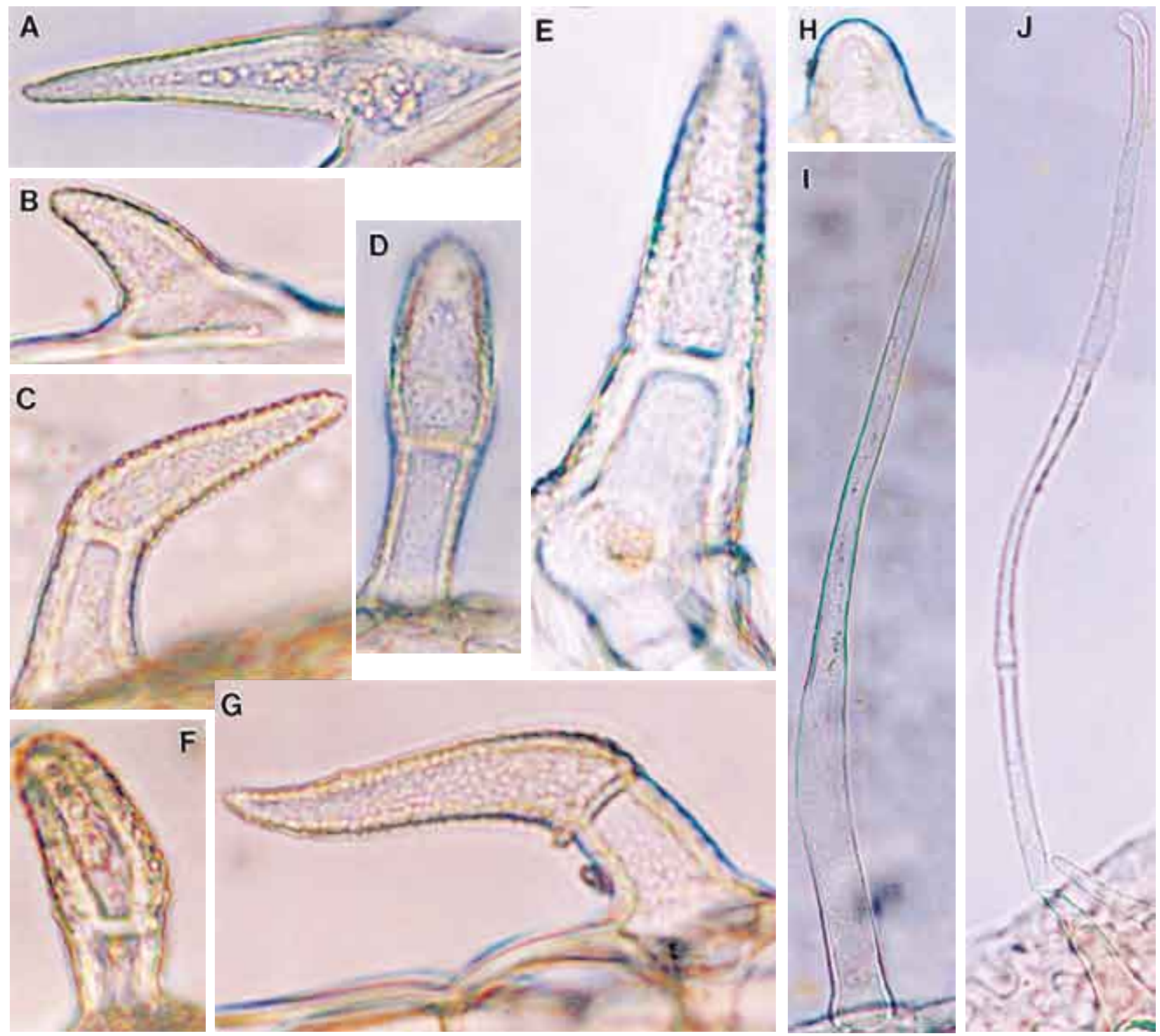

Fig. 4 A-J. Differently structured non-glandular trichomes of Dracocephalum moldavicum
A, B, H - Unicellular trichomes, x 1300,
C, G - 2-celled trichomes, bent x 1300,
D, E, F - 2-celled trichomes, erect, x 1300,
I, J -Long narrow trichomes, x 650. 

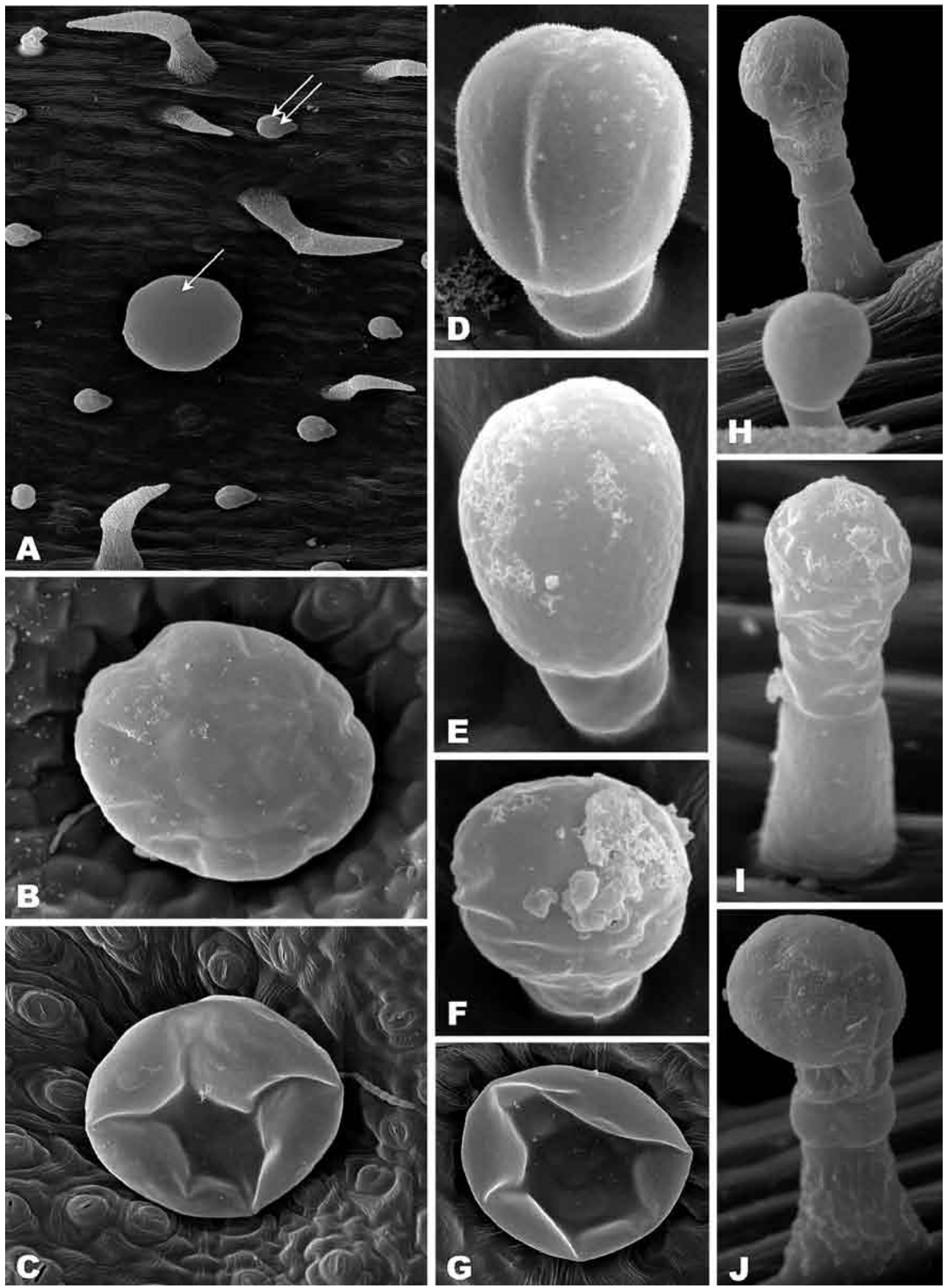

Fig. 5 Non-glandular trichomes and three types of glandular trichomes of Dracocephalum moldavicum

A-Bent non-glandular trichomes, peltate trichomes (arrow) and short capitate trichomes (double arrow), x 300,

$\mathrm{B}, \mathrm{C}-$ Peltate trichomes at different stages of functioning , B - x 700, C - x 550,

D-G - Short capitate trichomes at different stages of secretion accumulation and release, $\mathrm{x} 2700$,

H-J - Long capitate trichomes with different-sized cells of the stalk, H - x1100, I - x1800, J - x1500. 

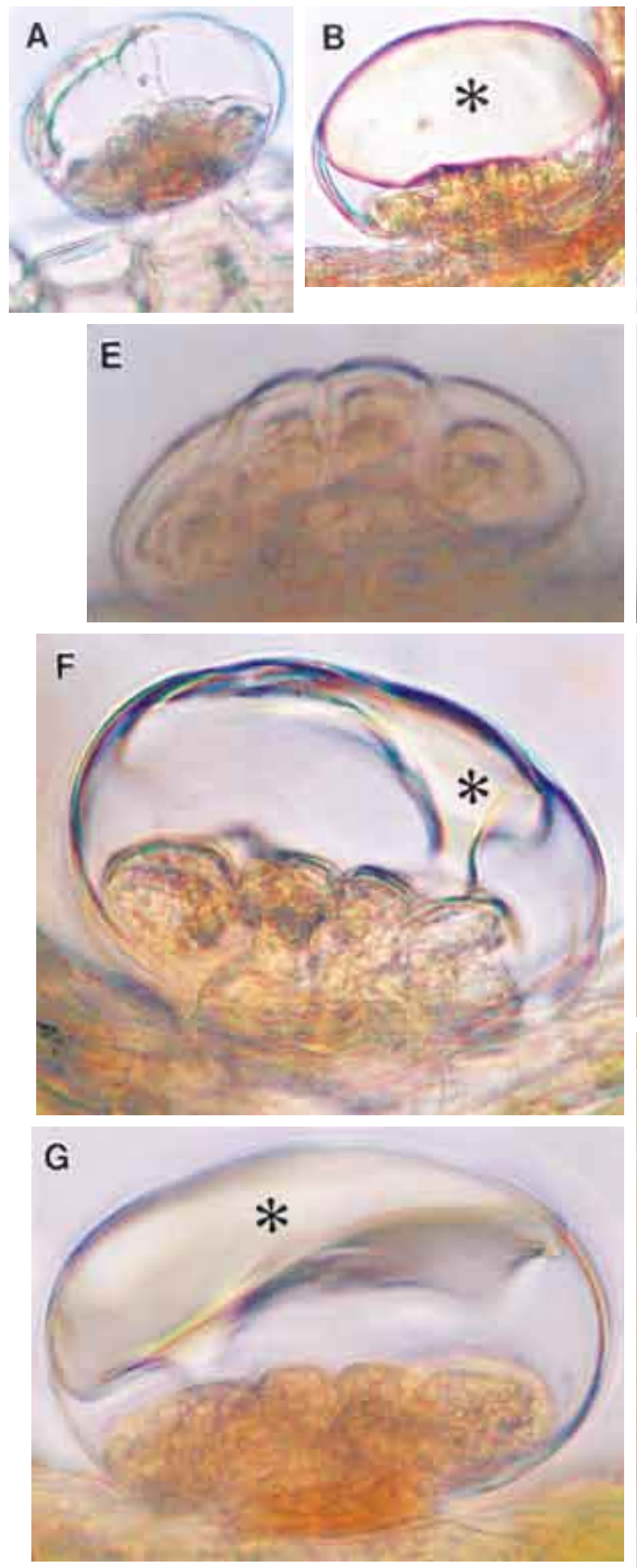
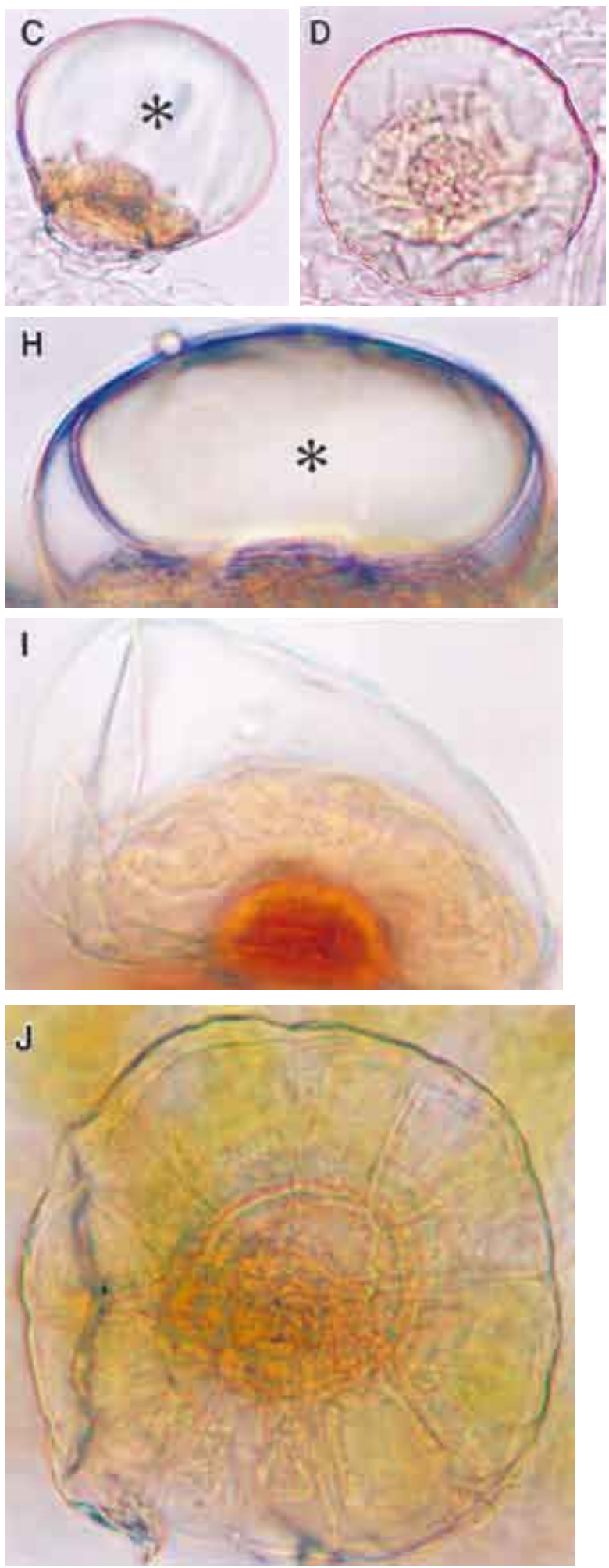

Fig. 6 Peltate glandular trichomes from different parts of the shoot of Dracocephalum moldavicum

A,B,C - Lateral view of trichomes with a large subcuticular space filled with secretion to a different degree,

D - Top view of a peltate trichome; A-D x 550,

E - Lateral view of a peltate trichome before the accumulation of secretion,

F-H - Peltate trichomes with grey secretion (asterisks) within the subcuticular space,

I- Trichome with a distorted cuticle after secretion release

$\mathrm{J}$ - Top view of a peltate trichome, E-J x1100. 

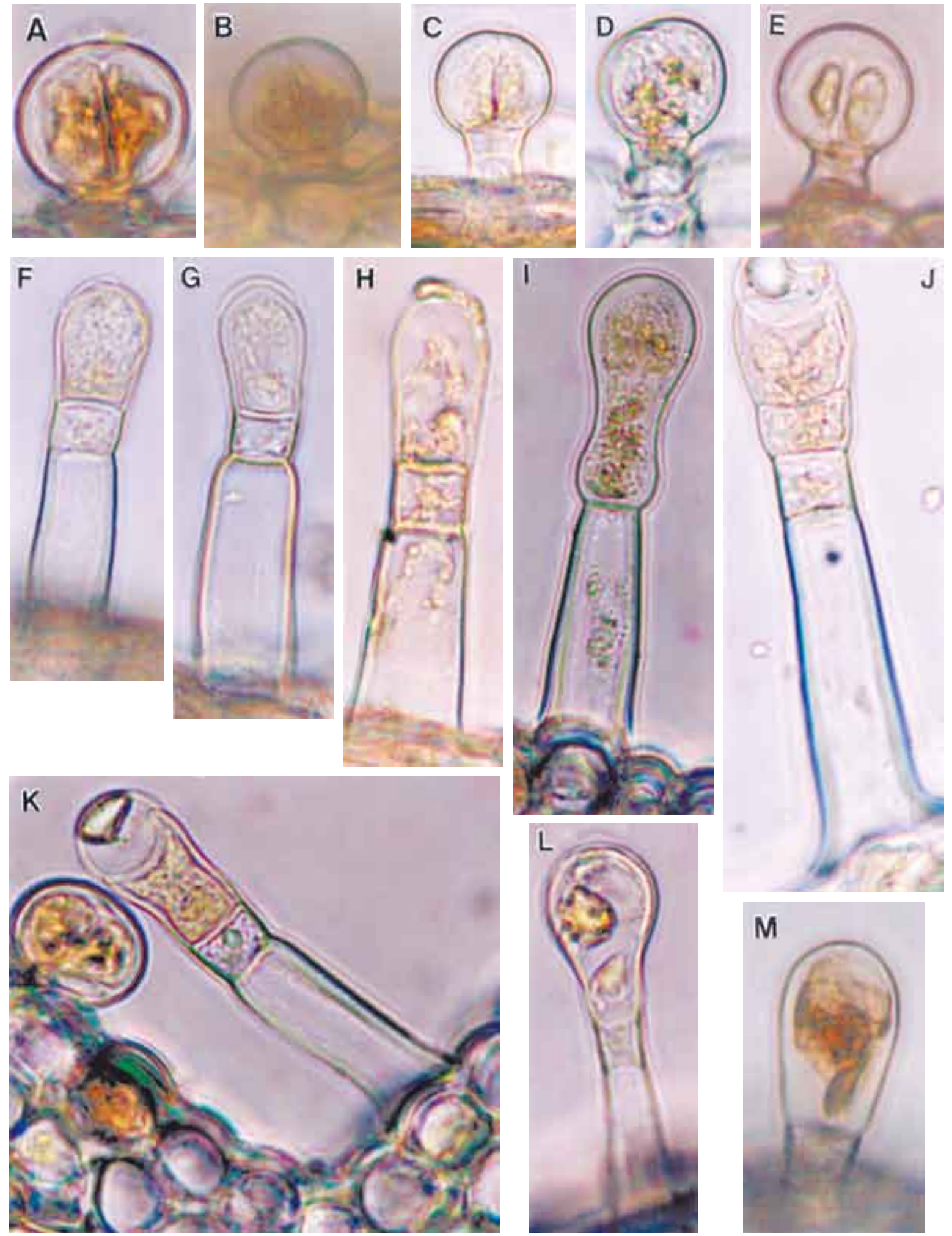

Fig 7. Short and long capitate glandular trichomes from Dracocephalum moldavicum shoots A-E - Short capitate trichomes with a two-celled head F-J, L, M - Long capitate trichomes with different-shaped unicellular heads $\mathrm{K}$ - Capitate trichomes: short and long; A-M x1100. 


\section{DISCUSSION}

The highest density of glandular and non-glandular trichomes on Moldavian dragonhead shoots is found on the calyx, bracts as well as on the upper part of the stem. These organs emit an intense scent and probably provide the most of essential oils.

The corolla of Dracocephalum moldavicum secrets essential oils produced by two types of hairs: peltate and short capitate trichomes. Trichomes of these types occur on the plant organs of different species of the family Lamiaceae (B o sabalidis and Tsekos, 1982; Cantino, 1990; Schultze et al. 1992; Tele pova et al. 1992; Giuliani and Maleci B in i, 2008).

In addition to the abovementioned types of glandular trichomes, the osmophores, whose emission layer is made up of epidermal papillae, are responsible for scent emission from the corolla of the studied species. In many plant species, the osmophores are located within the corolla (F a h n , 1979; V o g e 1, 1990), or else on many other floral parts, e.g. on the stamen filaments (W e ry s zk o-Ch mie lew ska et al. 2007).

The three types of glandular trichomes (D, E, F), distinguished in the present study, occur on most of the investigated organs: the abaxial part of the calyx, on both sides of the bracts, on the leaves beneath the inflorescence as well as on the stem. But long capitate trichomes (type F) were not found on the petals of the corolla and on the adaxial part of the sepals.

There is also a variation in the distribution of non-glandular trichomes on dragonhead shoots. Arrect trichomes of type A and B occur on all the examined organs, with the exception of the corolla petals where long acerate trichomes of type $\mathrm{C}$ are only found.

Compared to the results of the studies on Moldavian dragonhead carried out by other authors, we found differences in the structure of certain types of hairs. Among short glandular trichomes, $\mathrm{K} \mathrm{u} \mathrm{bi} \mathrm{ak}$ (1959) described hairs with a 4-celled head. We did not observe trichomes with such a structure in the examined material. L y a p u n ow a et al. (1975) found peltate trichomes, consisting of 9-16 cells, whereas such trichomes were composed of 8-12 cells in the plants studied by us, which had also been recorded earlier by Kubiak (1959).

Our study shows that, among the long capitate trichomes (type F) in Dracocephalum moldavicum, there is a great diversity in the structure of the head and stalk. This applies to the head shape as well as to the number and structure of the cells composing the stalk. We observed different shaped cells of the head: close to spherical or elongated. Some of the elongated heads exhibited a narrowing at half length, while others showed a significant narrowing in the basal part. The stalk cells located nearest the head (1-2), due to the presence of a dense poorly vacuolized cytoplasm, can be classified as secretory cells. Only the lower, most elongated cell of the stalk was characterized by a high degree of vacuolization.

In several species of the family Lamiaceae, Giulian i and Maleci B in i (2008) showed that each type of glandular trichomes produced a specific type of secretion, with a unique chemical composition; however, the same substances were predominant in it, e.g. terpenes. It may also be presumed that in Dracocephalum moldavicum the particular types of glandular trichomes, which have, among others, different contents of polyphenols (which was demonstrated in the present study) and various monoterpenes (T e le p o $\mathrm{v}$ a et al. 1992), emit differing odorous compounds.

Pell m y et al. (1987) found in Actaea, and Schultze et al. (1992) in Melissa, that the volatile mixture produced by the floral corolla differed significantly from the scents emitted by the calyx and the remaining part of the plant. The abovementioned authors are of opinion that such differentiation is intentional, since different scent signals affect pollinating insects over long and short distances. These qualitatively different scents attract insects first to the plant, and then to the flower.

\section{CONCLUSIONS}

1. The present study demonstrated an uneven distribution of glandular and non-glandular trichomes on different parts of the shoot of Dracocephalum moldavicum. The highest density of trichomes was recorded within the inflorescence and on the upper part of the stem.

2. In Dracocephalum moldavicum, we distinguished 3 types of non-glandular trichomes and 3 types of glandular trichomes. The long capitate glandular trichomes showed high morphological differentiation.

\section{REFERENCES}

Bini Maleci L., Pinetti A., Servattaz O., 1992. Micromorphological and phytochemical researches on Teucrium massiliense L. [In:] R. M. Harley and T. Reynolds (eds) Advances in Labiate Science. Royal Botanic Gardens, Kew.

Bosabaldis A. M., Tsekos I., 1982. Glandular scale development and essential oil secretion in Origanum dictamnus L. Planta, 156: 496-504.

Cantin o P. D., 1990. The phylogenetic significance of stomata and trichomes in the Labiatae and Verbenaceae. J. Arnald Arbar. 71: 323-370.

E s a u K., 1973. Anatomia roślin. Państwowe Wydawnictwo Rolnicze i Leśne. Warszawa.

Fahn A., 1979. Secretory Tissues in Plants. Academic Press, London. 
Giuliani C., Maleci Bini L., 2008. Insight into the structure and chemistry of glandular trichomes of Labiatae, with emphasis on subfamily Lamioideae. Plant Syst. Evol. 276: 199-208.

Kubiak M., 1959. Pszczelnik mołdawski (Dracocephalum moldavicum L.) jako roślina cytrolowa. / Moldavian dragonhead (Dracocephalum moldavicum L.) as a citral plant. Acta Pol. Pharmaceutica XVI, 2: 141-151.

Li piński M., 1982. Pożytki pszczele, zapylanie i miododajność roślin. Państwowe Wydawnictwo Rolnicze i Leśne, Warszawa.

Lyapunowa P. N., Salo N. D., Sergienko T. A., 1975. An anatomical study of herb Dracocephalum moldavica L. Farmatsiia, 24(5): 15-20.

Maurizio A., Grafl I., 1969. Das Trachtpflanzenbuch. Ehrenwirth Verlag. München.

Ozkan M., Soy E., 2007. Morphology, Anatomy, Hair and Karyotype Structure of Salvia blepharoclaena Hedge and Hub. - Mor. (Lamiaceae), Endemic to Turkey. Pakistan J. Biol. Sci. 10(6): 893-898.

Payne W. W., 1978. A glossary of plant hair terminology. Brittonia 30(2): 239-255.

Pellmyr O., Bergström G., Groth I., 1987. Floral fragrances in Actaea, using differential chromatograms to discern between floral and vegetative volatiles. Phytochemistry, 26: 1603.

Rutkowski L., 1998. Klucz do oznaczania roślin naczyniowych Polski niżowej. Państwowe Wydawnictwo Naukowe.

Schulze W., Zänglein A., Hose S., Kubeczka K. H., Czygan F. C., 1992. Volatiles in Flowers of Balm (Melissa officinalis L.). [In:] R. M. Harley and T. Reynolds (eds) Advances in Labiate Science. Royal Botanic Gardens, Kew.

Shavarda A. L., Telepova M. N. Budantzev A. L., 1990. Srawnitielnoje izuczenie sostawa efirnych maseł i ultrastruktury železistych wołoskow lista u niekotorych Widow v. Dracocephalum L. Rast. Resursy, 3: 352-362.

Szweykowscy A., J., 2003. Słownik botaniczny. Wiedza Powszechna, Warszawa.
Telepova M. N., Budantzev A. L., Sherarda A. L., 1992. Etnde comparative de la secretion des terpens par les elements glandulaires foliaires chez differentes especes du genre Dracocephalum L. (Labiatae). Bull. Soc. Bot. Fr. 139, Lettres Bot. 3: 247-264.

Vogel S., 1990. The role of scent glands in pollination: on the structure and unction of osmophores. Amerind, New Delhi, India.

Weryszko-Chmielewska E., Chwil M., Sawidis T., 2007. Micromorphology and histochemical traits of staminal osmophores in Asphodelus aestivus Brot. flower. Acta Agrobot. 60(1): 13-23.

\section{Zróżnicowanie morfologiczne} oraz rozmieszczenie włosków mechanicznych i wydzielniczych na pędach Dracocephalum moldavicum $\mathbf{L}$.

\section{Streszczenie}

Przy zastosowaniu mikroskopii świetlnej oraz skaningowej elektronowej (SEM) badano strukturę, mikromorfologię i rozmieszczenie włosków na pędach Dracocephalum moldavicum L. Wyróżniono 3 typy włosków mechanicznych, 3 typy włosków wydzielniczych oraz papille osmoforu w epidermie korony. Stwierdzono, że największe zagęszczenie włosków mechanicznych i wydzielniczych występuje na abaksjalnej powierzchni kielicha, liściach przykwiatowych i w górnej części łodygi. Wykazano zróżnicowanie strukturalne w obrębie główki i trzonka długich włosków wydzielniczych. Podano wymiary poszczególnych typów włosków.

Przedstawiono różnice w budowie włosków tego gatunku w porównaniu z danymi z literatury. Na licznych fotografiach udokumentowano mikromorfologię poszczególnych typów włosków z ukazaniem bogatej ornamentacji kutykuli włosków mechanicznych. 